\title{
Anarchy or Transformation? Scenarios for Change
}

\author{
Robin Luckham
}

Nothing sharpens debate like crisis. The analyses presented in this Bulletin call attention to the interconnections between recession and the global arms race, between the crises in North-South and East-West relations. It is no longer possible to take decisions on any major global issue without considering how it relates to other items on the global agenda. We live in a state of interdependent disequilibrium.

To chart our way through the chaos we tend to construct ideologies, or cognitive maps of the world we live in [Geertz 1973; see also the discussion by Cox (1979) of the ideologies of the new international economic order]. Sometimes these maps are wholly implicit, their hidden structures only being revealed, piecemeal, when analyses are made or decisions taken regarding particular issues. Sometimes (as in the case of many academic disciplines, to the extent that they can be regarded as ideological as well as intellectual constructs) their structures are partly out in the open, the remainder being tidied away among the "other things being equal'. Development economics, for example, has excluded (arguably necessarily so) political and social questions from its theoretical purview. Interdisciplinary development studies arose from the discovery by many development practitioners that these criteria were too restrictive. Development studies in its turn has had more success in assimilating some areas of political and social enquiry (such as the role of the state in development) than others (like international conflict, military power, nationalism or fundamentalist religion), perhaps because the latter raise more serious difficulties for the assumption that development can be managed by national decisionmakers if they can only implement appropriate policies.

The past decade and a half of international crisis has witnessed a series of attempts to assemble comprehensive pictures of the global situation. They include the Brandt, Palme and Thorsson reports. But they also include a rehabilitation of geopolitics in more conservative political circles and within military establishments. The military budget requests and planning documents of the major western powers (and, no doubt, the strategic assessments of Eastern military planners) have for some years given prominence to energy and resources in the Third World. The second page of the annual Military Posture statement of the US Joint Chiefs of Staff for Financial Year 1985 for example, includes the map in Figure 1, depicting potential sources of conflict in 'resource rich regions of instability'. As pointed out in the Editorial (page 1; see also Commission on Security and Economic Assistance 1983) such views are already affecting the allocation of development assistance.

Development practitioners themselves need not adopt such a crude geopolitical view. But they must be able to put forward credible alternatives. One way of beginning this task is to consider the relative strengths and weaknesses of a number of the different scenarios for reshaping the international order that have emerged in recent discussions, presented here in the form of schematic flow diagrams.

The reader should recall that these are loose cognitive maps rather than developed theoretical structures. Moreover the areas of uncertainty are so wide that they are more like the maps of medieval cartographers than the precise lines of the Ordnance Survey. Each contains a mixture of logical statements, empirical assertions, normative prescriptions and unstated presumptions. They provide a reasoned base for the policy choices that have to be made in a complex and unstable international environment: desperate attempts to turn the angel of history forward. Nor are they necessarily invalidated by the objection (see the article by Holm in this Bulletin) that the relationships they assume - e.g. between military spending and slow growth - remain unproven. To be sure, if none of these relationships could be demonstrated, the scenarios would provide extremely

IDS Bulkin. 1985. vol 16 no 4. Institute of Development Studies. Sussex 


\section{POTENTIAL SOURCES OF CONFLICT}

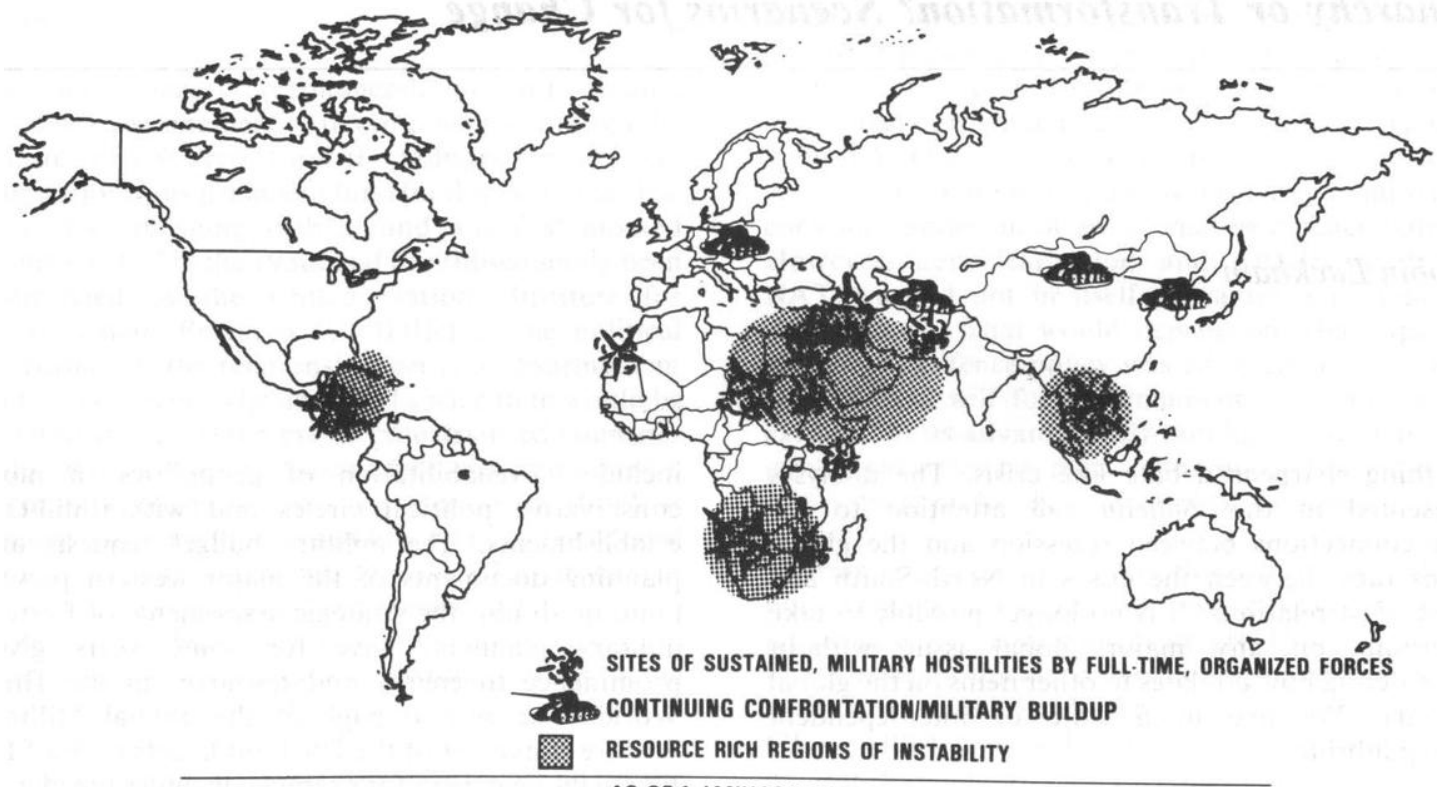

AS OF 1 JANUARY 1984

MAP I- 2

poor foundations for policy. Nor would they be much use (however valid their analysis) if they could not identify the political forces that might implement their vision.

But if our scenarios provide so uncertain a map of the international situation and so are difficult to translate into practical politics, would we not do better without them? Would it not be preferable to deal with development issues on a piecemeal basis as they arise in each country, in case linking them too closely to other items on the global agenda (like disarmament) gets in the way? There are two simple answers to such objections..First, the view that the issues are separable also implies a global scenario (in my view a false one) of a piecemeal world of autonomous economies and separable national parts. Second, development practitioners already have to contend with a number of scenarios which have been put onto the international agenda by internationally powerful groups.

Four of the six scenarios presented in this article (the Trilateralist, the Monetarist-Militarist, the European Gaullist and 'Socialism-as-it-Actually-Exists') fall into the category of proposals for restoring one form or another of the international status quo. None of them, however, envisage a neutral stability. Rather they are orchestrated around the power and interests of particular dominant classes and nation-states. Nor indeed do they really provide for a real status quo, for they all assume the continuation of the arms race and provide little basis for curbing the cyclical momentum of the global economy. They represent, in sum, four different ways of riding a tiger.

The fifth and sixth scenarios (the Brandt-PalmeThorsson and the Global Transformation scenarios) provide two alternative paradigms (not necessarily the only ones) for planned change in the international order: in the one case through a systematic aggregation of piecemeal reforms instituted in the main from above by the more progressive members of the global policy-making elite; in the other case through global transformations linked to political mobilisation from below.

The proposals put forward in the Trilateral and Brandt-Palme-Thorsson scenarios can be pinned down to specific publications and groups of people; even though there are some internal differences of opinion amongst the latter not reflected in the scenarios. The others are my own reconstructions of four distinct world views which have tended to emerge in international discussions, without necessarily being explicitly formulated in the form shown in the diagrams: they are 'ideal types'.

Let us briefly consider each of the six scenarios in turn. The trilateral scenario summarises the ideas and policies advanced in the reports of the Trilateral Commission in the 1970s (a useful but somewhat 
jaundiced view of which is provided in Sklar 1980). The Commission was founded by David Rockefeller, the Chairman of the Chase Manhattan Bank, Zbigniew Brzezinski, later to become President Carter's National Security Advisor, and other 'eminent private citizens' from the United States, Western Europe and Japan (hence the term 'trilateral'). Its formation was a direct response to the collapse of the Bretton Woods system of international payments and the decline of US global power after the Vietnam war. The height of its influence was under the Carter administration in the United States, President Carter himself and several of his key advisors being members.

Broadly speaking, the trilateralists proposed restructuring the international economic order on the basis of managed capitalism and partnership between US, Western European and Japanese corporate capital; while preserving the foundations of Western global power on the basis of the NATO alliance and arms control negotiations with the USSR. Their policies toward the Third World were less clear, being founded on the one hand on strategic interests and support for 'political order' and on the other hand on claims to moral authority established through aid and advocacy of human rights. In the event, the less liberal strands in the trilateralist programme prevailed (for an insider's view of how this came about see Brzezinski 1983). It was the Carter administration which created the Rapid Deployment Force and initiated the increases in military spending that were carried through under President Reagan.

The proponents of the monetarist/militarist scenario, on the other hand, were brought to prominence by the final collapse of the political consensus around which managed capitalism, the politics of the centre, EastWest detente and arms control had been based. This collapse was partly brought on by the second phase of the recession which began in the late 1970s; but it also reflected the deteriorating international political situation.

The scenario's most distinctive characteristic has been the combination of liberal economics and muscular geopolitics. The one does not follow logically from the other; indeed there are monetarist economists (including President Reagan's former Budget Director) who regard military spending as a major obstacle to sound finance. However, the juxtaposition is not accidental. For economic restructuring - both under monetarist economic policy in the advanced economies and 'structural adjustment' in the ldes - has almost inevitably caused major social dislocations, hence conflict. Moreover, the 'new right' has given as much emphasis to competition among states and national economies as to competition in the market between firms. The former, unlike the latter, encourages the use of military power to protect or acquire non-market advantages. The temptation to do so has been especially strong for declining world powers, such as the USA and the UK - all the more when the military sector is one of the few in which they have been able to keep a competitive edge.

Gaullist scenarios on the other hand have taken state power and national capitalism as their starting point. The 'project' for France embarked on by General de Gaulle and followed with remarkable consistency by his successors, including the Socialist government of President Mitterand [Luckham 1982] has been based on six inter related priorities: an 'independent' defence and nuclear deterrent; a self-sufficient defenceindustrial base, supported where necessary by arms exports to the Third World; planned capitalism with an emphasis on the high-technology sectors; dialogue with the USSR and closer economic relations with Eastern Europe; cultivation of political alliances in the Third World through aid policy and well publicised support for the NIEO; and direct military presence in regions of French influence, notably Francophone Africa and the Pacific

The relative decline of the US economy, economic protectionism on both sides of the Atlantic and tensions within NATO are the context of proposals for what would in effect be a European version of the Gaullist project. The outlines of such a scenario have begun to emerge from discussions of European defence and political cooperation that have taken place in the revived Western European Union and other international fora. If these initiatives were to succeed, they would have far-reaching implications for European economic cooperation, for East-West relations and for Europe's relationships with the Third World, spelt out in the diagram. Nevertheless, the political viability of the scenario is far from established, due to the well-known difficulties of European cooperation on economic let alone political issues.

The scenario of 'Socialism-as-it-actually-exists' [Bahro 1978] can only be extrapolated from the USSR's international behaviour, since explicit statements of the rationale for Soviet and East European policies are few and far between. Its most striking features are the normalisation of relationships with the capitalist world economy [Valkenier 1979]; and the assertion of the USSR's superpower parity with the USA, based in turn on consolidation of the Eastern bloc and the primacy of the military sector within the Soviet economy [Holloway 1983]. These goals have in practice been given priority over the construction of socialism and support for states of socialist orientation in the Third World. 
Thus in some respects the arms race and the system of blocs have brought about a symmetry between East and West, most directly visible in the military sector. Nevertheless the symmetry has been disturbed by the tendency of the Soviet Union to seek room for manoeuvre beyond the accepted framework of the Cold War. This is a tendency which many Western policy-makers have regarded as a source of international instability (as with Soviet 'intervention' on behalf of revolutionary governments in the Third World). One could equally well argue that it opens up opportunities for change, both in the Third World where the non-aligned movement has made full use of the rivalry between East and West, and in Europe where it complements the Ostpolitik of West European governments.

All four of the above scenarios still envisage a world trapped in the arms race and unable to transform a stagnating and polarised world economy. The BrandtPalme-Thorsson scenario ${ }^{1}$ offers a programme for global reform. The proposals of the three Commissions from which this scenario is extracted are fully discussed elsewhere in this Bulletin. I shall merely reiterate the two major criticisms that have been made of them. First, that it cannot be assumed, without further analysis, the resources released by military cuts would in fact be used for development. And second, that the political processes by which such an ambitious programme of reform could be carried through in a world in which power politics are the dominant principle, have not been adequately considered.

The global transformation scenario addresses such political questions more directly, although it still incorporates many of the specific Brandt-PalmeThorsson proposals. It is perhaps even more of an extrapolation than the other scenarios. Although there is no shortage of analysis of individual issues (disarmament, ecological balance, Third World selfreliance etc.), there have been few attempts to pull them together within an analytical framework or as a political programme. (The 'Out of Crisis' project of a

1 Inga Thorsion has reminded me that similar conclusions were arrived at by another major international commision. that on Reshaping the International Order (RIO) chaired by lan Tinbergen. group of leading European socialist economists spells out a programme for European recovery, from which elements of the scenario are drawn [Holland 1983]. But it does not deal centrally with either disarmament or the Third World. ${ }^{2}$ The UN University's programme on Peace and Global Transformation has developed scenarios for global change, but has not yet placed them on the international agenda.)

Unlike Brandt-Palme-Thorsson, this scenario emphasises the scope for unilateral action by states or groups of states alongside multilateral negotiation. It is less sanguine about free market mechanisms. And it identifies groups and political forces that could be mobilised to press for change, rather than relying on the political will of policy-makers. Nevertheless it shares some of the same difficulties. It is not clear how conflicts of interest (e.g. between advanced industrial countries restructuring their industry behind protective barriers, and NICs hoping to increase their manufactured exports) would be dealt with. The analytical and practical basis for a number of the assertions in the scenario could be questioned. Is 'selfreliant' development really a viable option for developing countries with open economies and small domestic markets? Could solutions to social injustices in the Middle East or Southern Africa be found without major armed conflict or at the very least without escalation into a broader global confrontation? Would powerful groups in the industrial North permit the dismantling of the major military alliance systems without putting up a struggle? Would political movements operating outside established power politics, however widely supported, be strong enough to oblige them to do so? These questions are asked to emphasise that any global scenario is only a starting point. It can provide some sense of how a series of interrelated changes might fit together. But until the more detailed issues are realistically tackled, the global agenda will continue to be set by the established international power brokers.

Since this article was written the Third World fbut not the disarmament dimension has been added by the Report of the Socialist International Committec on Economic Policy: 1985. 


\section{Notes to the Scenarios}

Each scenario depicts West-East relations on the horizontal axis and North-South relations on the vertical axis.

The top diagram portrays the economic dimensions of these relationships and the lower diagram the political/strategic, although the argument of this paper is that the two are systematically related. In lieu of a three-dimensional diagram the connections have been made, where possible, in the text.

Arrows with a single head indicate unidirectional or unequal relationships; and with a single head two-way or balanced relationships. Thick lines are used for strong relationships, broken lines for weaker ones and no lines when there is little or no relationship.

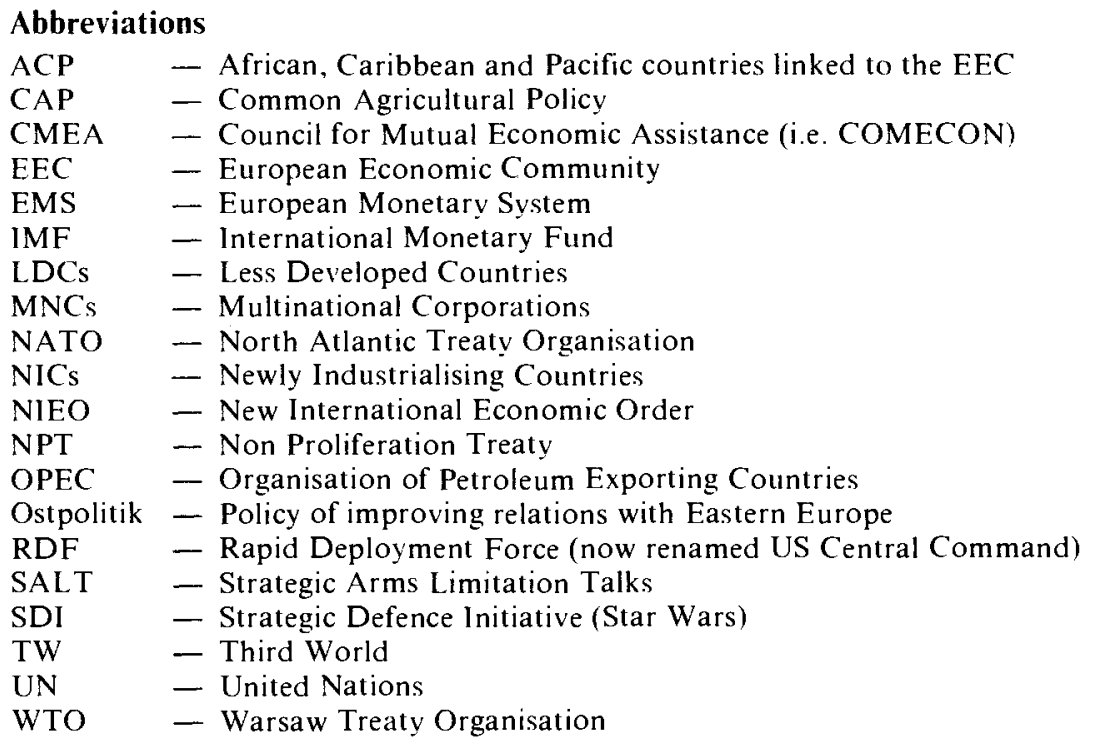


THE TRILATERALIST SCENARIO

'Management of interdependence". Coordinated expansion of industrial market economies (USA. Europe, Japan) achieved through corporatist alliances between state, large firms and organised labour.
Socialist economies increasingly dependent on the world economy for credit, technology and grain. increasing the West's economic leverage. Increase in joint ventures between socialist enterprise and MNCs.

MNCs relocate capital and production toward NICs.

OPEC surpluses 'managed' under international energy agreements. as well as being recycled through arms transfers and international credit mechanisms.

LDCs pulled into recovery by revival of world raw material demand. international credit expansion and increased multilateral aid. 'Political order'. Investment by MNCs and planned capitalism provide framework for international development.

Restructuring of Pax Americana on multilateral basis through NATO and US-Japan Security Treaty. Consolidation of bi. partisan consensus on defence and foreign policy within the major Western democracies. Coordinated increases in NATO military spending.

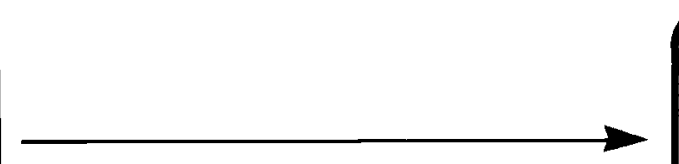

Restoration/preservation of 'strategic balance' between NATO and Warsaw Pact within framework of detente and bilateral East-West arms control negotiations (SALT, etc.).

NICs helped to become more 'self reliant' as regards their security (the Nixon doctrine) and their arms production.

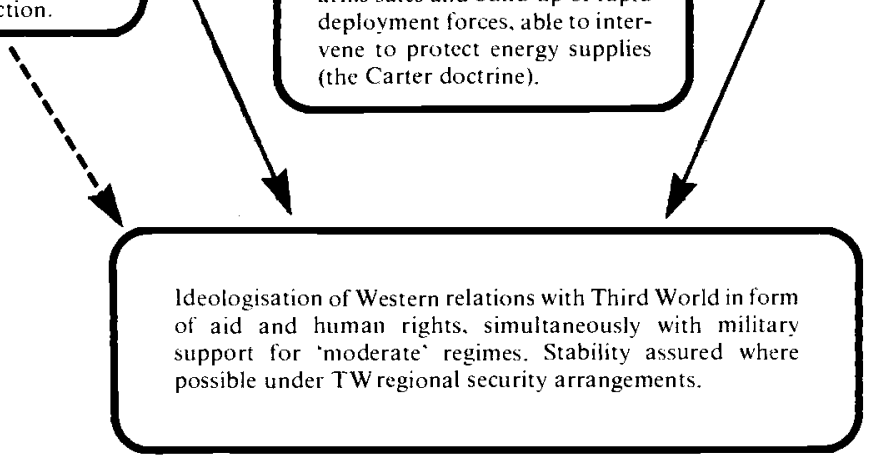




\section{THE MONETARIST/MILITARIST SCENARIO}

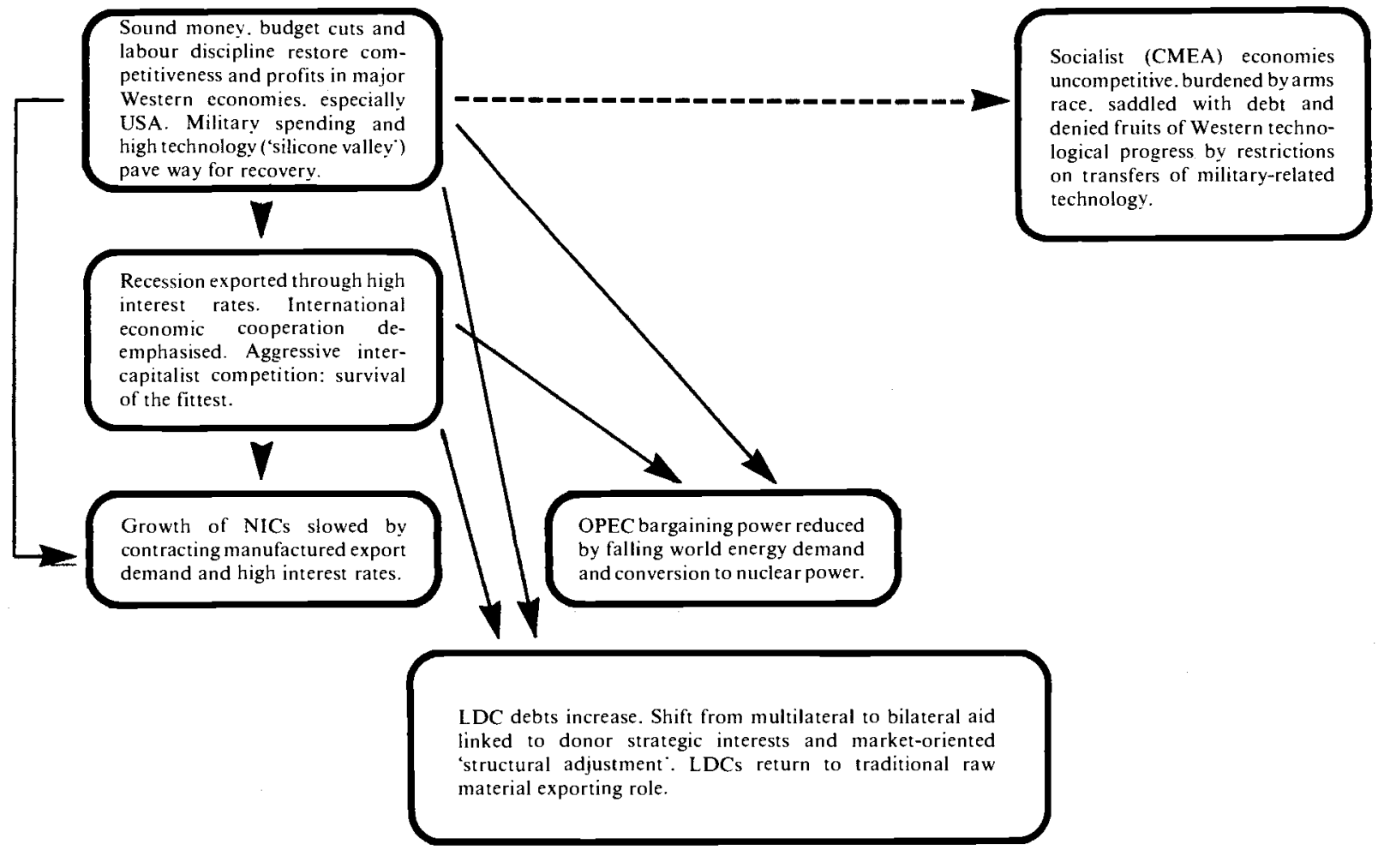

'Resurgent America'. New military programmes (Star Wars. Air-Land Battle. RDF. Cruise. Pershing etc.) not merely close 'window of vulnerability' but reestablish global US military supremacy.

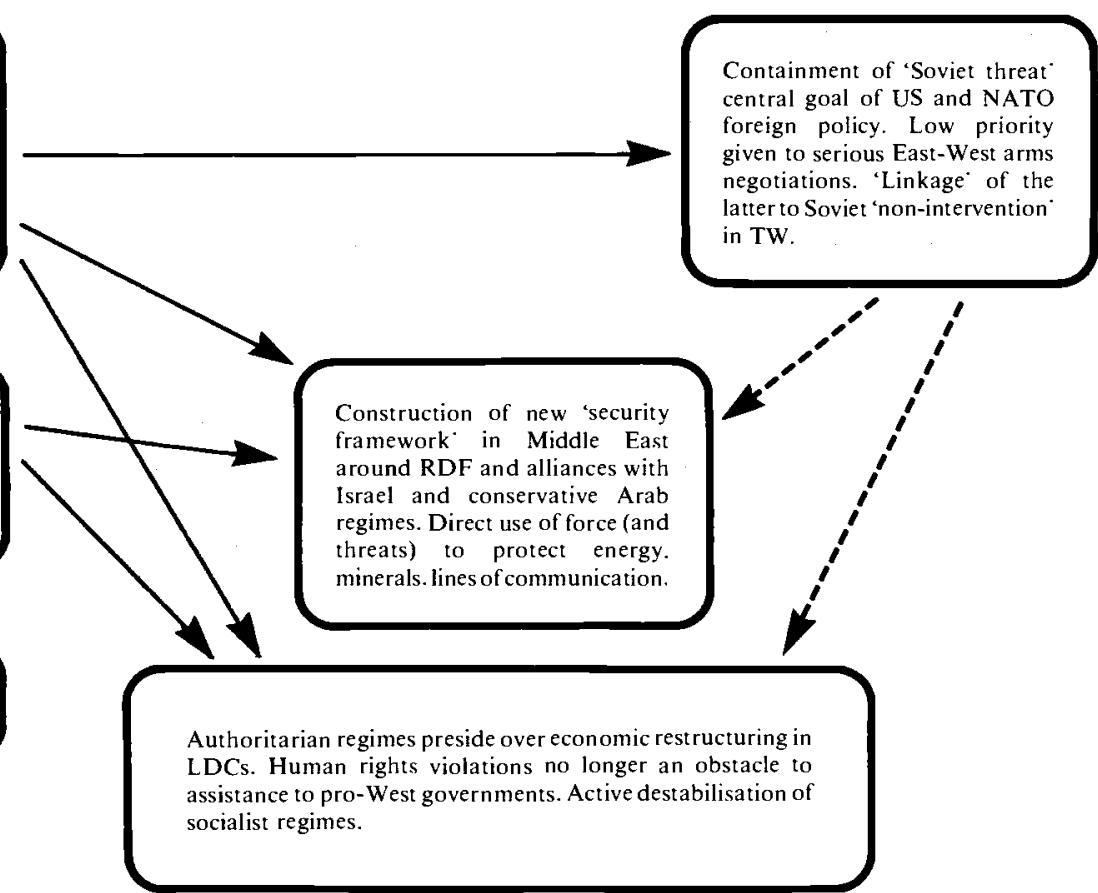




\section{THE GAULLIST EUROPE SCENARIO}
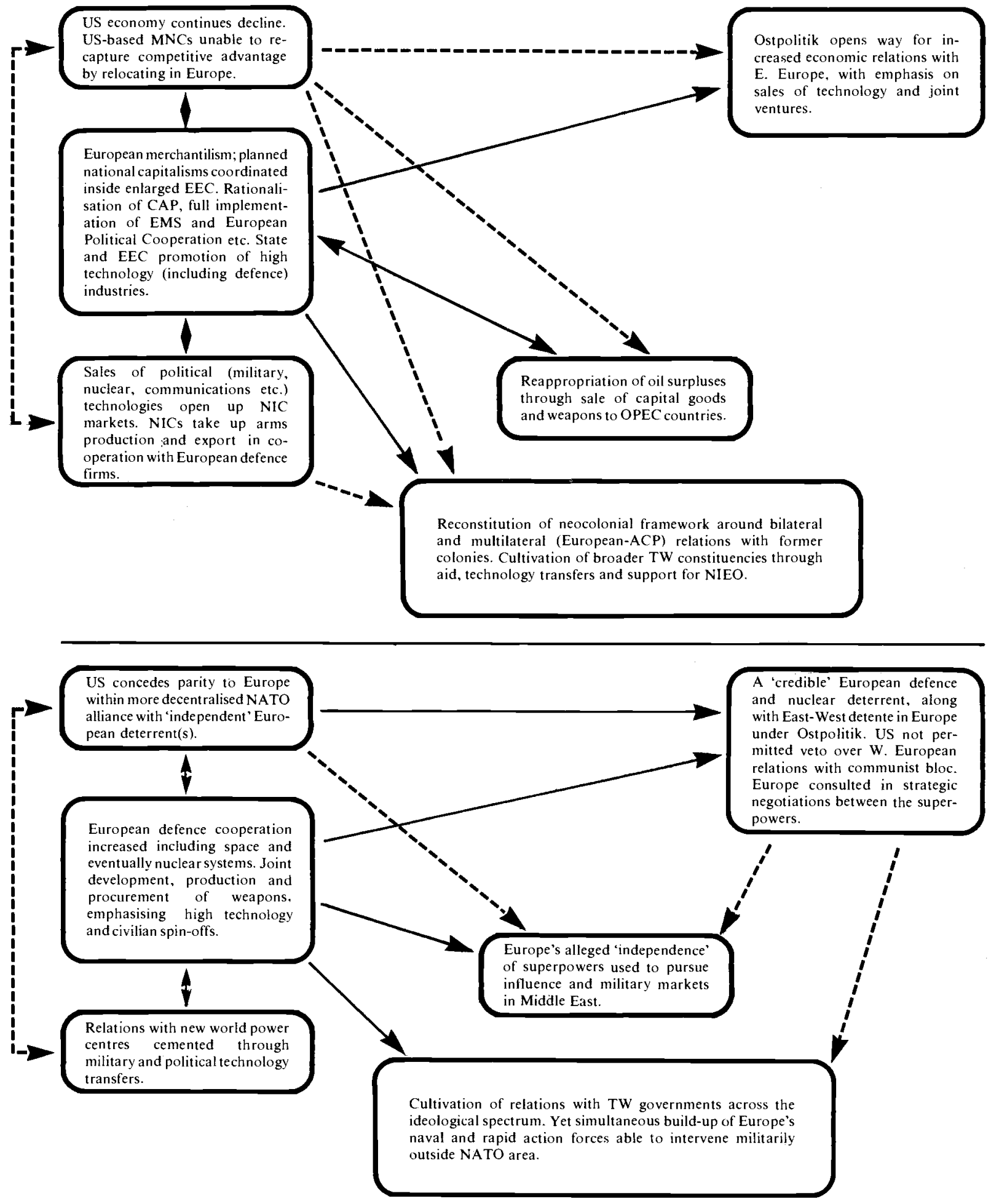


\section{'SOCIALISM-AS-IT-ACTUALLY-EXISTS' SCENARIO}

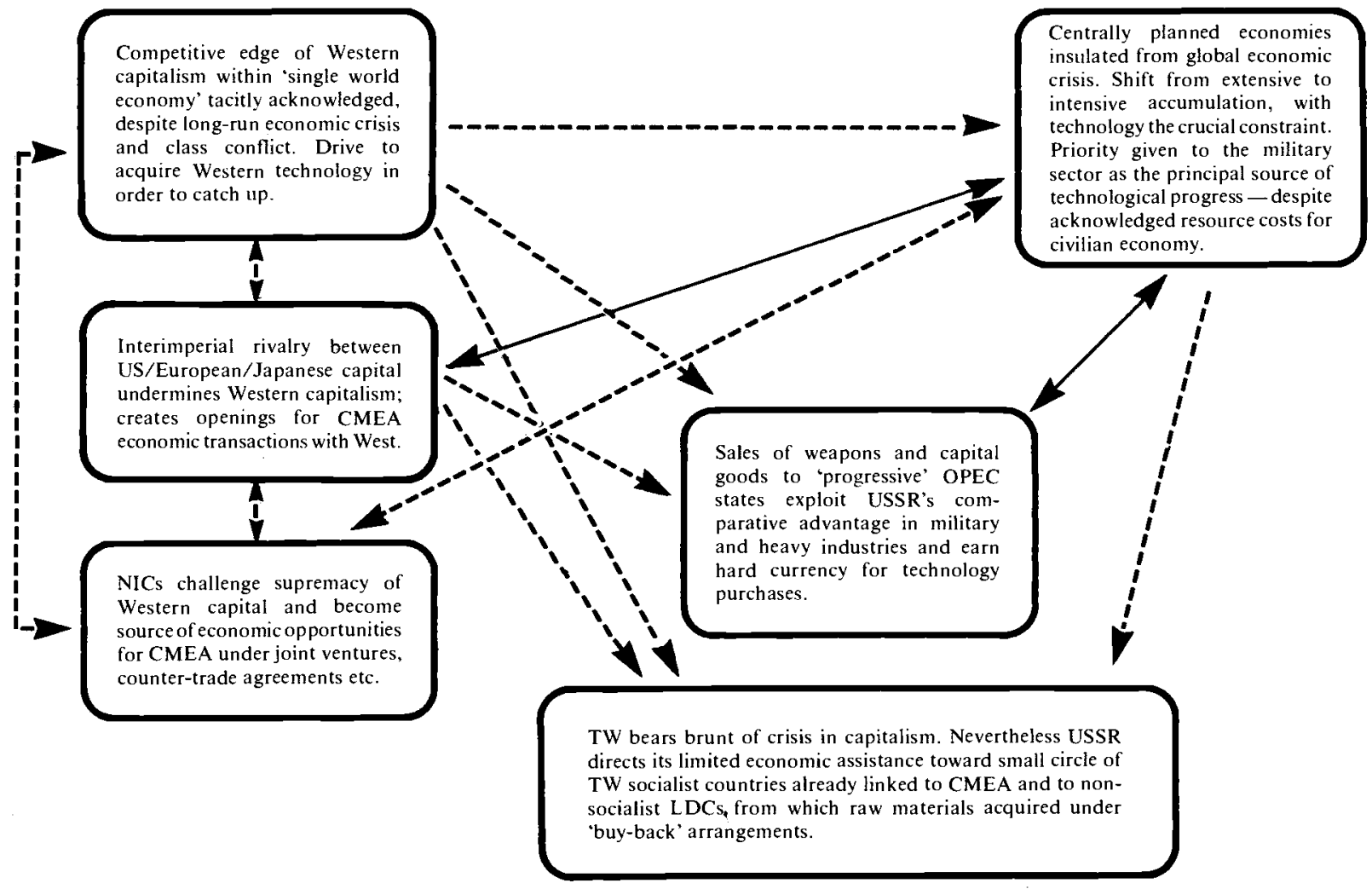

USSR maintains strategic parity with USA, and status as a globa! superpower. Arms control negotiations restrain US attempts to regain the strategic advantage through SDI technology, and reestablish the basis for detente.

NATO alliance undermined by interimperial rivalries and rise of peace movements. East-West European detente proceeds through bilateral government contacts and multilateral Helsinki framework.

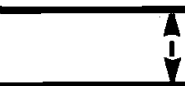

Emergence of alternative power centres in NICs cautiously welcomed, with misgivings concerning their relations with the West and over nuclear proliferation.
Soviet military power ensures cohesion of the WTO and safety of the socialist camp. Detente allows class struggle to continue, gradually shifting international correlation of forces in favour of socialism.

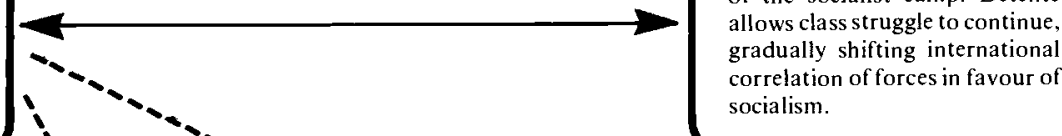




\section{THE BRANDT-PALME-THORSSON SCENARIO}

Economic recovery of North achieved through military cuts. resource transfers to South. removal of protection ist barriers and international monetary reforms (increased liquidity, stable exchange rates and long-term funding of Third World debts). Institutions of international economic management (World Bank. IMF) strengthened and reformed, Increased Southern participation.

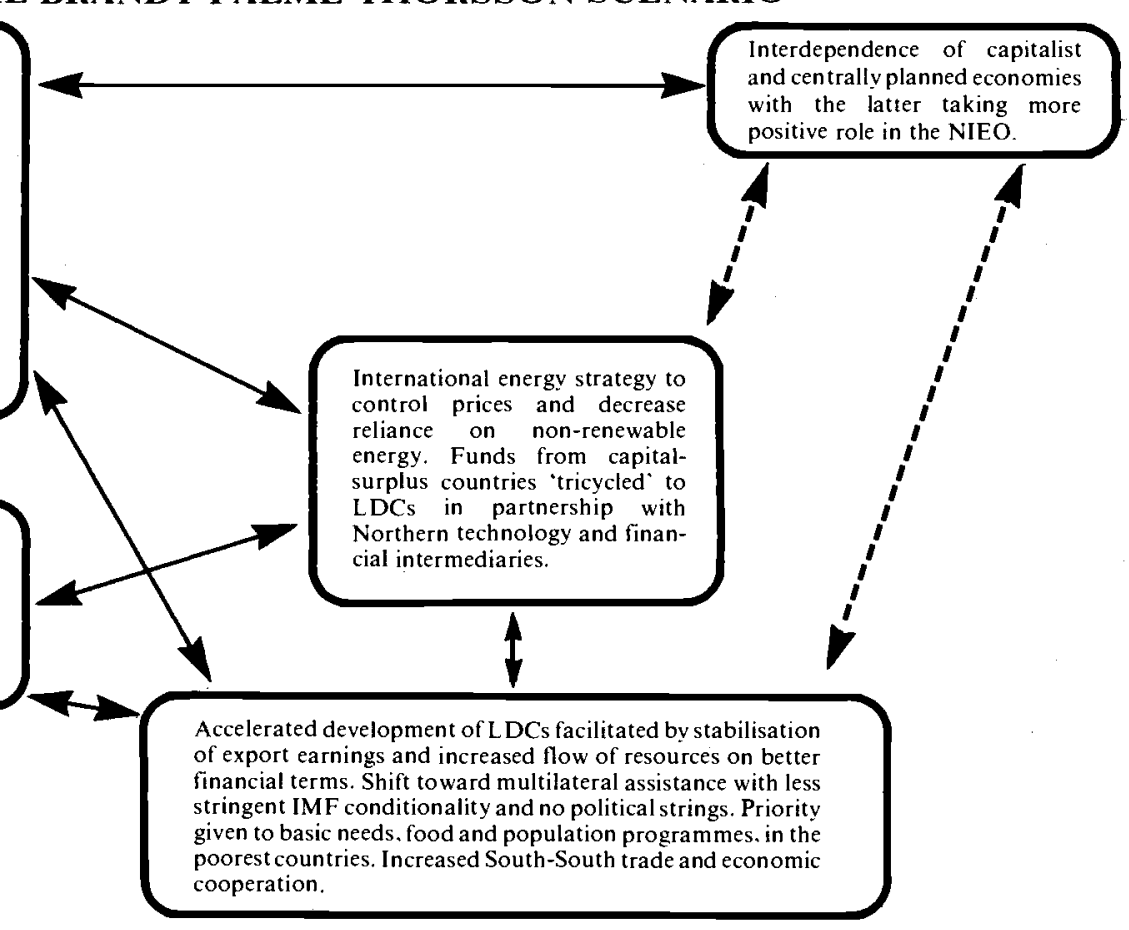

Multipolar global economy. Relocation of industrial production toward South encouraged by dismantling of Northern protective barriers, sharing of technology and codes of conduct for MNCs.

Accelerated development of LDCs facilitated by stabilisation of export earnings and increased flow of resources on better given to basic needs. food and population programmes, in the

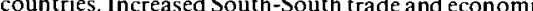

Common security on basis of NATO-WTO strategic parity. NATO foregoes space weapons and new missiles in Europe pending multilateral nuclear cuts and chemical disarmament. Reduced military spending and conversion to civilian production. Stronger UN

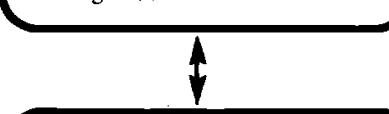

Ostpolitik creating climate for further Confidence Building Measures, mutual force reductions and nuclear-weaponfree-zone in Central Europe.

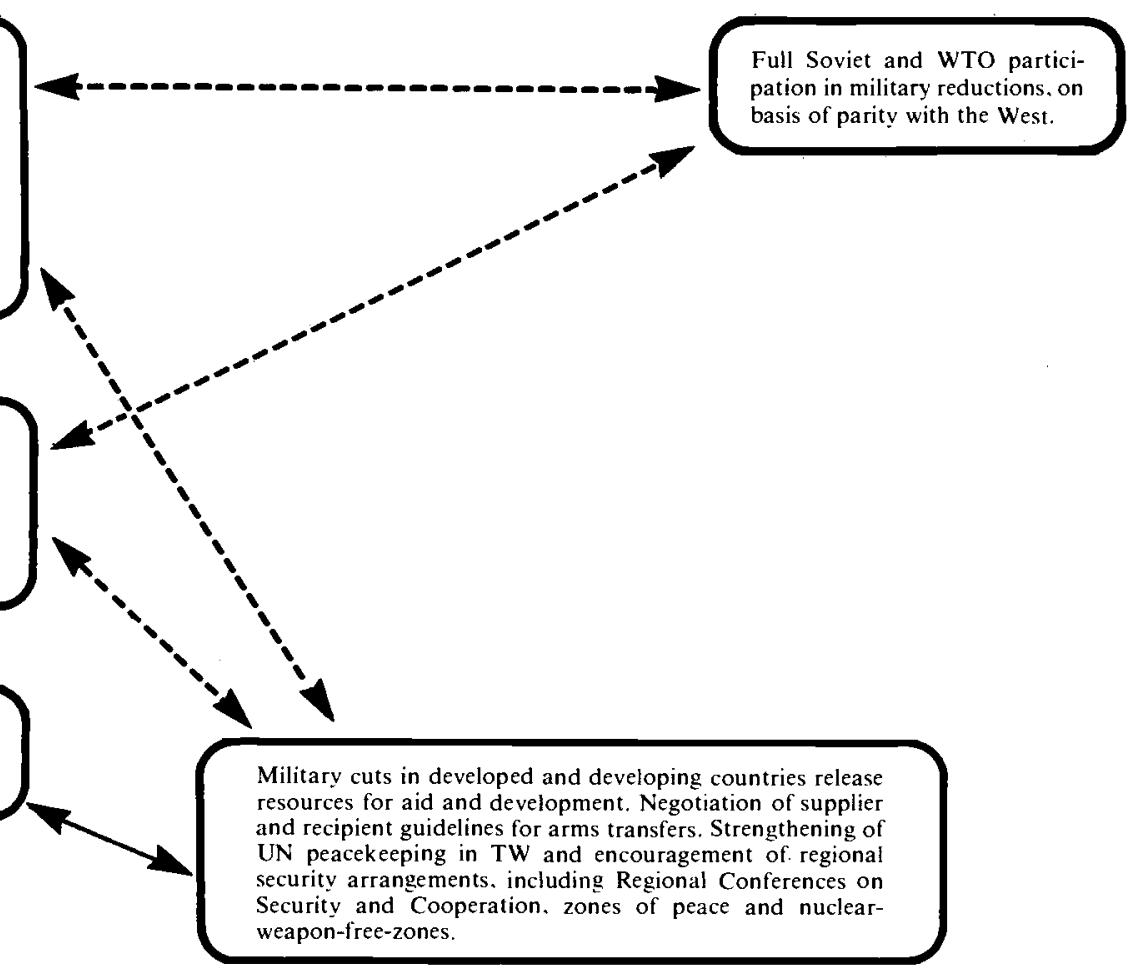

Broader adherence to NPT and fuller international control of sensitive parts of nuclear fue cycle. inces and recipient guidelines for arms transfers. Strengthening of peacekeeping in TW and encouragement of. regional Security and Cooperation. zones of peace and nuclearweapon-free-zones. 


\section{THE GLOBAL TRANSFORMATION SCENARIO}

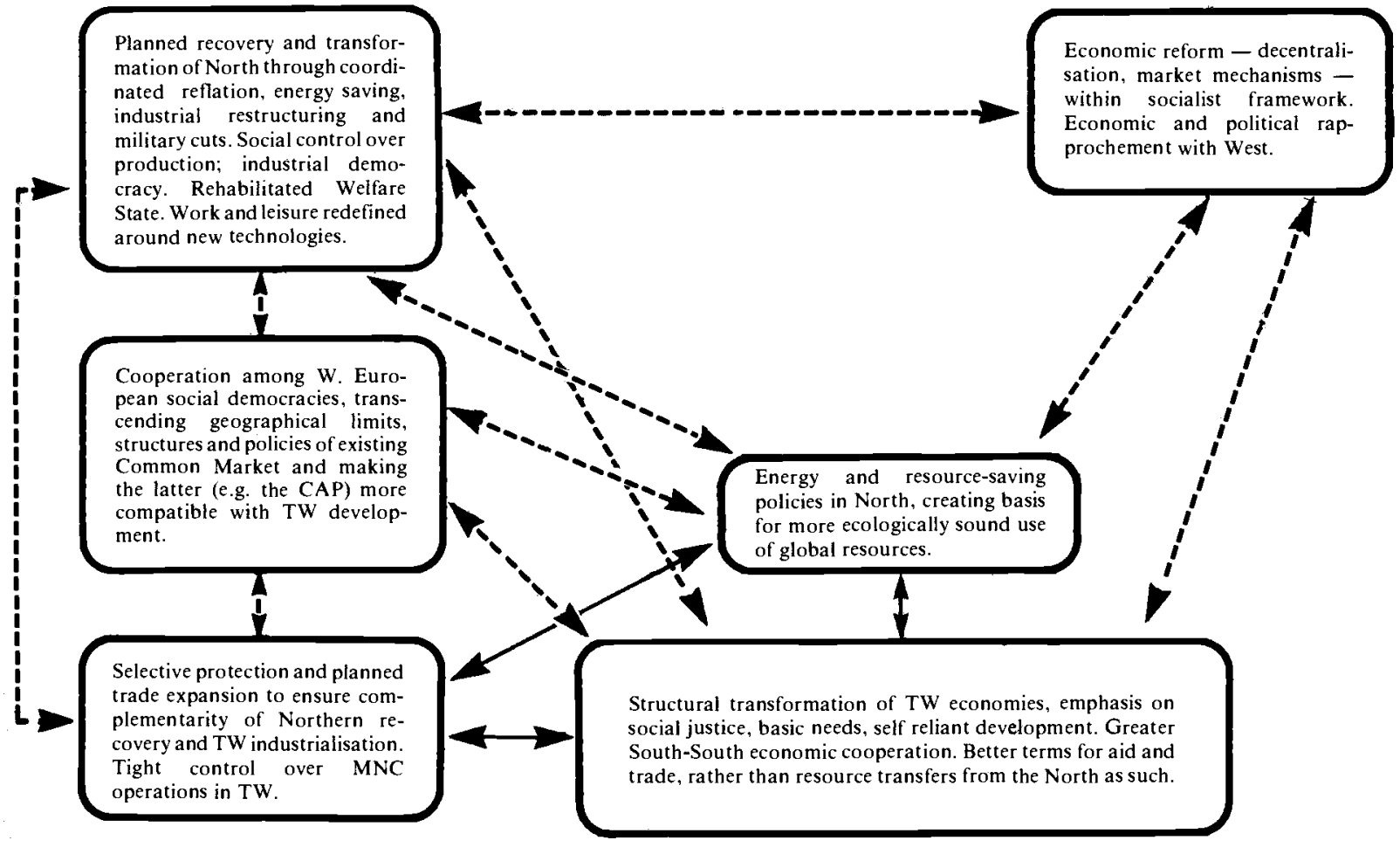

Nuclear freeze, then unilateral arms reductions, paving way for multilateral negotiations. Deep military spending cuts and planned conversion to civilian uses. Political mobilisation through new (peace, greens, women's) social movements as well as trades unions and socialist parties.

\section{$\hat{t}$}

Step by step dealignment o Europe from NATO, starting with the withdrawal of Cruise and Pershing. Nuclear-weaponsfree-zone in Europe and development of an aiternative non-nuclear defence.
Full implemention of NPT. Tight control over arms transfers, especially to authoritarian regimes.

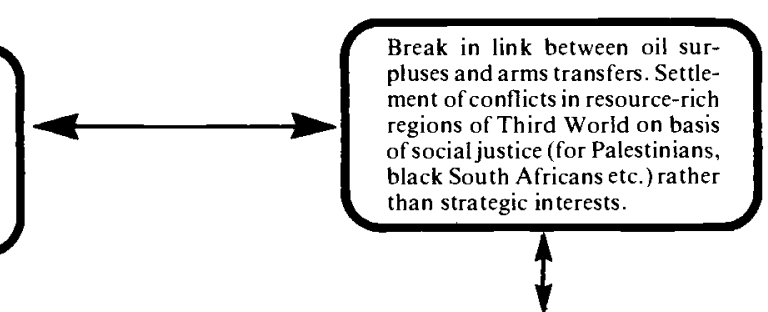

Non-alignment and demilitarisation in TW, releasing resources for development. Military delinking from North (reduced arms transfers, military aid, training, bases, etc.). Non-aggression pacts, nuclear-weapons-free-zones and 'zones of peace'. Stronger UN and regional peacekeeping machinery. 


\section{References}

Bahro, R., 1978, The Alternative in Eastern Europe, New Left Books, London

Brzezinski, Z., 1983, Power and Principle - Memoirs of the National Security Advisor, 1977-1981, Farrar, Strauss, Giroux, New York

The Commission on Security and Economic Assistance, 1983, A Report to the Secretary of State, Washington DC

Cox, R. W., 1979, 'Ideologies and the New International Economic Order: reflections on some recent literature', International Organisation vol 33 no 2 Spring

Geertz, C., 1973, 'Ideology as a cultural system' in The Interpretation of Cultures, Basic Books, New York

Holland, S., 1983, Out of Crisis - A Project for European Recovery, Spokesman, Nottingham
Holloway, D., 1983, The Soviet Union and the Arms Race, Yale U.P., New Haven

Luckham, R., 1982, 'French Militarism in Africa', Review of African Political Economy, no 24, May-August

Sklar, H., 1980, Trilateralism, The Trilateral Commission and Elite Planning for World Management, Black Rose Books, Montreal

The Report of the Socialist International Committee on Economic Policy, 1985, Global Challenge: from Crisis to Cooperation: Breaking the North-South Stalemate, Pan Books, London

United States, 1984, United States Military Posture FY1985, The Organisation of the Joint Chiefs of Staff, Washington

Valkenier, E., 1979, 'The USSR, the Third World and the Global Economy', Problems of Communism, July-August

\section{IPRA CONFERENCE 1986}

The International Peace Research Association (IPRA) will be holding its eleventh biennial General Conference at the University of Sussex on 13th-18th April 1986.

The theme of the Conference will be 'Just Peace Through Global Transformation: Towards a Global Decade for Peace'. The Conference reflects the concerns of the UN International Year of Peace (1986) with sessions on conflict resolution, human rights, militarisation of language and culture, non-violence, peace and development, peace education and peace movements.

IPRA was founded in 1964 to advance interdisciplinary research into the conditions of peace and the causes of war and other forms of violence. There are now members in 55 countries. Over the past 21 years, IPRA has encouraged worldwide cooperation designed to assist the advancement of peace research and, in particular, has aided the promotion of national and international studies and teaching related to the pursuit of peace. IPRA has facilitated contacts and cooperation between scholars and educators throughout the world, and has also supported the dissemination of the results of peace research.

Previous IPRA General Conferences have provided a valuable forum for peace researchers from all over the world, the discussion of new research ideas and the launching of new initiatives, often of a transnational character. In a period of rapid change and development in the field of peace research, IPRA's role is becoming increasingly important. This is evident by the growing numbers of members and participants from Third World countries.

For further information about IPRA and the General Conference please contact Dr. Gari Donn, c/o Robin Luckham, Institute of Development Studies, at the University of Sussex, Falmer, Brighton BN1 9RE, Sussex, or telephone 0273202516. 


\section{Books Received}

Charles Edquist, Capitalism. Socialism and Technology: a comparative study of Cuba and Jamaica, Zed Books Ltd., London, 1985

Catherine Overholt et al (eds), Gender Roles in Development Projects, Kumarian Press, West Hartford (Conn.), 1985

Ingrid Palmer, The Nemow Case, Kumarian Press, West Hartford (Conn.), 1985

Transnationals Information Exchange, 'Meeting the Corporate Challenge: a handbook on corporate campaigns', TIE Report 18/19, Amsterdam, 1985

Lloyd Timberlake, Africa in Crisis: the causes, the cures of environmental bankruptcy, Earthscan, London, 1985

Mary E. Burfisher and Nadine R. Horenstein, Sex Roles in the Nigerian Tiv Farm Household, Kumarian Press, West Hartford (Conn.), 1985

United Nations, Performance Evaluation of Public Enterprises in Developing Countries: Criteria and Institutions, New York, 1984

Kathleen Staudt, Agricultural Policy Implementation: a case study from Western Kenya, Kumarian Press, West Hartford (Conn.), 1985

Gordon Hathway, Low-cost Vehicles: Options for moving people and goods, Intermediate Technology Publications, London, 1985

Marilyn Carr (ed), The AT Reader: theory and practice in Appropriate Technology, Intermediate Technology Publications, London, 1985
East-West Center, Accessions List - Documents: 1983-1984, Resource Materials Collection, Honolulu, Hawaii, 1985

Murray Chapman and R. Manswell Prothero, Circulation in Population Movement: Substance and Concepts from the Melanesian Case, Routledge and Kegan Paul, London, 1985

Peter J. Rowe and Christopher J. Whelan (eds), Military Intervention in Democratic Societies, Croom Helm, Beckenham, 1985

M. D. Leonor (ed), Unemployment, Schooling and Training in Developing Countries, an ILO-WEP Study, Croom Helm, Beckenham, 1985

Robert B. Potter, Urbanisation and Planning in the Third World, Croom Helm, Beckenham, 1985

Theodore Panayotou (ed), Food Policy Analysis in Thailand, Agricultural Development Council, Bangkok, 1985

Birgit Brock-Utne, Educating For Peace: A Feminist Perspective, Pergamon, Oxford, 1985

George Irwin and Xabier Gorostiaga (eds), Towards an Alternative for Central America and the Caribbean, ISS/George Allen and Unwin, London, 1985

Edward Dommen and Philippe Hein (eds), States, Microstates and Islands, Croom Helm, Beckenham, 1985

Aidan Foster-Carter, The Sociology of Development, Causeway, Omskirk, 1985

Robert N. Gwynne, Industrialisation and Urbanisation in Latin America, Croom Helm, Beckenham, 1985

North South Institute, Women in Industry: North - South Connections, Ottawa, 1985 